\title{
The use of illustrated stories as a proposal to improve multiple intelligences and students' learning approach based on CLIL
}

\section{El uso de cuentos ilustrados como una propuesta para mejorar las inteligencias múltiples y el enfoque de aprendizaje de los estudiantes basado en CLIL.}

Gordillo Obregon, Gilma. ${ }^{1}$, Obregon Mayorga, Angel. ${ }^{2}$ \& Logroño Becerra, Mónica. ${ }^{3}$

Recibido: 12-09-2019 / Revisado: 10-10-2019 /Aceptado: 27-10-2019/ Publicado: 04-11-2019

\begin{abstract}
.
DOI: https://doi.org/10.33262/cienciadigital.v3i4.1.985

The purpose of this intervention proposal is to demonstrate that using illustrated stories as educational material in the Primary Education classroom using CLIL (Content and Language Integrated Learning) is a very appropriate idea to learn the English language. This proposal will be analyzing the advantages of using this method based on multiple intelligences. Illustrated tales inside CLIL will help English teachers to create a perfect environment for the students to learn a second language and at the same time to develop their critical thinking. A didactic storybook has been related for the students of the first years of Primary Education, as this is a creative way to connect the students' learning with their real life. This work will show important aspects such as positive and negative features that might occur in the learning of the English language. Multiple intelligences and the use of illustrated stories, which have been taken from the Ecuadorian culture, will promote enthusiasm, leadership, motivation, and positivism in students. As a conclusion, it can be said that a creative didactic proposal will be presented and evaluated and will be a positive educational resource for students who are learning English as a second language in Ecuador and to improve the students' learning approach based on CLIL.
\end{abstract}

1 Escuela Superior Politécnica de Chimborazo, Chimborazo, Ecuador, gilma.gordillo@espoch.edu.ec

2 Escuela Superior Politécnica de Chimborazo, Chimborazo, Ecuador, paul.obregon@espoch.edu.ec

3 Escuela Superior Politécnica de Chimborazo, Chimborazo, Ecuador, ma_logrono@espoch.edu.ec 
key words: Illustrated tales, Content and Language Integrated Learning (CLIL), multiple intelligences.

\section{Resumen}

El propósito de esta propuesta de intervención es demostrar que el uso de cuentos ilustrados como material didáctico en el aula de educación primaria después de CLIL (Aprendizaje Integrado de Contenido y Lenguaje) es una idea muy apropiada para aprender el idioma inglés. Esta propuesta analizará las ventajas de usar este método basado en inteligencias múltiples. Los cuentos ilustrados dentro de CLIL ayudarán a los maestros de inglés a crear un ambiente perfecto para que los estudiantes aprendan un segundo idioma y al mismo tiempo desarrollen su pensamiento crítico. Se ha creado un libro de cuentos didáctico para los estudiantes de los primeros años de educación primaria, ya que es una forma creativa de conectar el aprendizaje de los estudiantes con su vida real. Este trabajo mostrará aspectos importantes como las características positivas y negativas que pueden ocurrir en el aprendizaje del idioma inglés. Las inteligencias múltiples y el uso de historias ilustradas, que han sido tomadas de la cultura ecuatoriana, promoverán el entusiasmo, el liderazgo, la motivación y el positivismo en los estudiantes. Como conclusión, se puede decir que se presentará y evaluará una propuesta didáctica creativa y será un recurso educativo positivo para los estudiantes que están aprendiendo inglés como segundo idioma en Ecuador y para mejorar el enfoque de aprendizaje de los estudiantes basado en CLIL.

Palabras clave : Cuentos ilustrados, contenido y aprendizaje integrado del lenguaje (CLIL), inteligencias múltiples, educación primaria.

\section{Introduction}

Today, the English language throughout the world has become a necessity and a great challenge in our globalized world, especially in the work environment. Without this language, communications among countries would be difficult, being a limitation for the development of the people. The English language has gained space during these years, as well as within the Content and Language Integrated Learning (CLIL) curriculum for the Primary Education, which provides to the progress of the future professionals in the whole world. Its main objective is to train people holistically, thus having a promising future. For this reason, teaching the English language has become the most important thing to do in order to create solid bases from the very first years of Primary Education in Ecuador.

Most students who speak Spanish have several disadvantages to learn English; the present study aims to figure out these limitations highlighting the use of illustrated stories in English as a source and didactic material within the CLIL classroom in Primary Education in Ecuador. This proposal is very positive to achieve important learning of English as a second 
language and should be motivating for students. It is valuable to note that most children like illustrated stories because it is part of their daily lives.

The benefit of using illustrated stories will be highlighted by its efficiency, versatility in educational issues, establishing many communicative, creative and linguistic skills, thus increasing student's motivation.

The study is divided into 5 parts and structured as explained below. The first section lists and describes the aims that are considered to obtain with the creation of illustrated stories proposal as a teaching didactic material used in a CLIL classroom, in one subject directed in English in the first period of Primary Education in Ecuador.

The second section resides of the Literature review, which is established on the emphasis of Multiple Intelligences (MI) and with CLIL's educational, economic and communication world. Another critical aspect highlighted in the Literature review is the matter that deals with the difficult situation facing Ecuador with the teaching of the English Language, the contrasting methodological factors that had run the Ecuadorian country to work out bilingual projects in its persisting public and private education. After this, we may find the characteristics of the illustrated stories as a resource for bilingual teaching and finally a consideration on the importance of the use of illustrated stories in the classroom and inside the curriculum of Primary Education in this country.

Some important aspects such as Self-esteem and self-concept are mentioned in the literature because this is an important affective factor that can affect the learning process of the students within the classroom. William and Burden (1999) mentioned, "The conception that students have of their own ability as students are based largely on the character of the interactions that occur in the classroom" (p.105).

According to Garner and McIntyre (1993), Anxiety is another important aspect that affects when students are trying to communicate in a foreign language. Anxiety is related to personality and to the classroom environment. Students with low anxiety will learn much better and will reach their purpose faster. Muñoz (2002) mentioned that "A person who is not afraid to do the ridiculous will risk using a word or expression that does not dominate or make mistakes completely" (p.29).

\section{Justification of the problem}

The increasing concern in bilingüal education in Ecuador has seen a big change during all these years, becoming monolingual schools into bilingual and adding the English language as the principal or second principal language in many educational centres. Nowadays, the interest in the theory of multiple intelligences (MI) proposed by Howard Gardner (1983) has 
also been increasing in a world where nowadays all societies need to know more languages in order to be more capable to be successful. In other countries, adequate knowledge of other languages, mainly English, is very important as part of education.

Today, the quality of English language education in Ecuador is improving in all its bilingual education programs from initial programs to higher. In August 2011 according to law 0110074, all students must receive five hours of English a week and the language must be taught from the first years of study. The Ecuadorian state established the development of texts, curricula and new programs for the growth of the English language in the country (Ecuador, 2011)

Ecuador is a country where the CLIL system has been applied in Primary Education since 2007, where a subject is taught through the English language changing from monolingual schools to bilingual, replying slowly to the new requirements of the new world, giving great interest to the acquisition of the English language from primary education.

The origin and the principal idea of this Proposal lie in the deficient of didactic resources that the Ecuadorian education has. No many resources are applied within the CLIL class to develop multiple intelligences in all subjects. The agency in charge of education in Ecuador had designed grammatical books for all its English second language programs in the public Primary schools, but the resources are not enough to create new techniques to be applied in class for a specific subject in a bilingual education teaching. Thus, the proposal to develop an illustrated story for teaching English as a second language is an important idea to promote the real critical learning application of the English language and the content in bilingual education in the Primary Education in Ecuador. CLIL approach will focus on the development of a new illustrated story to create active and independent students who usually do not acquire by memorization but by other imaginative ways based on the MI theory in a CLIL classroom.

\section{A brief analysis of the state of- the art}

The Main approach to be organized in this dissertation focuses on such as Multiple Intelligences (MI). This theory states that intelligence is not an inborn and perpetual feature along with life. Important investigators of the period studied MI, such as Gardner (2006) who explained the intelligence according to the context and as long as the context changes through life, the intelligence varies too. These investigators evidenced 9 different kinds of intelligence.

Another theory which is considered in this study is based on content and language integrated learning (CLIL) approach to develop a new creative proposal as a didactic tool to put in action with students in class, to activate all multiple intelligences (MI) and performing them in order to apply an authentic assessment in the Ecuadorian Primary Bilingual Education. CLIL is the 
educational method that involves teaching studies about a subject in a second language with its four components 4Cs (Content, communication, cognition, and culture), designed to teach Science, Math, History, Music, or Arts with language and content. An additional element that has to be established is the motivation defined as one of the main elements in the process of learning. "The educational motivation, influenced by the main bilingual initiatives, as in Canada, was to get design and to adapt existing language teaching approaches to provide an expansive range of students with higher levels of ability "(Marsh, Pavon, \& Frigols, 2013).

Today the CLIL concept has been transferred as a way to improve learning and access to many more languages also incorporate new practices within the curriculum as a single piece. CLIL has been gaining more people who use it in the world not only in European countries but also in Latin America. Nowadays, some countries need more teachers using CLIL since it is observed that this method will be used in more countries around the world.

Loannou Sophie and Pavlou, P (2011) said, that the CLIL has three characteristics "a) The learning of an additional language (AL) is integrated with the content topics, like science, history or geography. Students learn a language and through the content is provided to them. b) CLIL has its origin in different sociolinguistic and political contexts and relates to any language, age and level of education from early childhood, primary school, secondary education, and vocational training. In this sense, the CLIL responds to the proposal of the continuing education program for all citizens, where multilingualism and multiculturalism are believed to advertise unification, understanding and mobility among Europeans".

\section{Aims of the proposal}

The main purpose of this Dissertation is to design an illustrated tale as an intervention proposal to be offered to the CLIL students from the Primary Education in Ecuador as a learning strategy based on multiple intelligences theory (MI) related to a specific subject of CLIL. This proposal will provide a highly rewarding and motivating experience to the students in the process of their significant learning.

\section{Specific Aims of the proposal}

In order to accomplish the principal aim of the investigation we need to:

- To explore the teaching-learning process through reading, storytelling and illustrated stories based on a practical and didactic proposal developed for this Master's Dissertation.

- To emphasize the importance of illustrated tales for teaching and learning process in Primary Education in general, as a didactic and motivating resource in a CLIL class for gaining a second language. 
- To identify the benefits that illustrated stories have for Ecuador, the process of teaching-learning and the teaching of the English language.

- To obtain conclusions and opinions on how to improve the teaching of a second language through the use of illustrated stories.

\section{Methodology}

The methodology used for the elaboration of the illustrated stories as a didactic resource was based on the method of communicative teaching to improve Multiple Intelligences and students' learning approach based on CLIL method. As a reference the illustrated tales were elaborated with a methodology in order that they have the contact with the teacher as a motivational pre-activity or aa a warm-up in class to activate the students' knowledge in the following way: (language input - structured input - communicative output).

The class should include a speaking section in which the teacher needs to do a communicative activity like a brainstorming as an input at the beginning of the class. Both tales will work as input before the teaching content where the CLIL teacher has to be in control of the activity. Finally, the production and creative activity come as an individual or as teamwork based on the tale and the objectives of the content. The proposals were elaborated to improve multiple intelligences and students' learning approach based on CLIL and to rescue ancestral histories of Ecuador which are an important cultural part for the history of that country.

The stories were selected by their functionality, and didactic flexibility in the classroom, due to their cultural importance; Features that can capture the attention of all students and disclose relevant information to be taught to future generations of Ecuadorian students and activate their minds for a better creative and meaningful learning in a CLIL class. That is how two stories were selected, elaborated and designed in total to be illustrated for the Primary Education students of Ecuador.

When talking about their contents, it was necessary to highlight the main ideas of each story and omit information not very relevant to short stories for Ecuadorian children of Primary Education. The first story with a total of 828 words provided by Annex 1, whose origin comes from the Sierra region called "The story between Juan and the Taita Chimborazo", and the second from the Ecuadorian East called "Jumandy the Amazonic Warrior", with 798 words provided by Annex 2, both with a great literary importance, and very rich in cultural identity and folklore.

Innovation in foreign language teaching began in the 19th century and became very popular in the 20th century. It directed to a number of diverse methods, separately demanding to be the main development over the previous or contemporary methods of learning. 
The first applied linguistic methods include some made by Jean Manes, Heinrich Gottfried Ollendorff (1803), Henry Sweet (1845), Otto Jespersen (1860), and Harold Palmer (1877), all of them are cited in the book "Approaches and Methods in Language Teaching" by Richards and Rodgers (2001). All the authors after them working on site the language teaching philosophies and approaches based on linguistic and psychological theories and they left many of the specific practical details for others to invent.

There are many methodologies for the process of teaching a second language as well as methodologies that have been based on the use of the first language and others in the foreign language in which some of them are based on the total non-use of the first language. and many other methodologies have different educational contexts. An example of one of them is integrated content and language learning (CLIL), in which students learn a subject using a foreign language. "CLIL refers to situations where subjects, or parts of subjects, are taught through a foreign language with dual-focused aims, namely the learning of content, and the simultaneous learning of a foreign language" (Marsh, 2002, p11). Below is a list of some of the most representative methods:

- Reading Approach

- Audiolingual Method

- Grammar Translation Approach

- Direct Approach

- Content and Language Integrated Approach (CLIL)

- Communicative Approach

- Total Physical Response Approach (TPR)

\section{Reading Approach}

The acquisition of vocabulary in this method is much more important than the grammatical rules. This approach takes into account the translation of the text in a necessary way and aspects such as pronunciation are not important. This methodology was built on the development of the reading skill and it is being addressed to university students.

\section{Audiolingual Method}

This method is born by the contrast of the reading method and has some aspects that are very similar to the Direct Approach, which will be developed below. The pronunciation is a very significant aspect which tries to come to seem as much as possible to the native accent. The skills are developed with an orderly process using continuous information of the repetition method to learn to speak a second language. This approach holds that vocabulary is learned with its use in the context of a specific word in a sentence to know its meaning in the following order: 
- Listening skills

- Communicative skills

- Reading skills

- Writing skills

\section{Grammar Translation Approach}

The use of this approach within the class is done through the use of the first language in the process of teaching and communication of a second language between the student and the teacher. It is considered one of the oldest methods to learn a new language based on the primary study of a list of vocabulary regardless of its meaning. Within this methodology, the grammatical part of a text has a lot of value to analyze its rules. The content of the text was not the main point of this teaching methodology. Thornbury (2010) stated that "Grammar Translation (GT) had become an antithesis of the good practice of teaching". It should be noted that other important skills of a language were not taken into account as is the case of the pronunciation. The activities carried out were based on the translation of the first language and the foreign language. It can be noted that this approach doesn't allow the development of communication so important in any language.

\section{Direct Approach}

This methodology was built on the narration of texts and on the conversation between the student and the teacher inside of the classroom. It is important to mention that in this method the culture of the language is an important factor and which is learned implicitly. The teacher will always be in charge of taking the initiative and all the activities carried out by the students will be followed by questions also made by the teacher based on the topics that are being studied. This approach is grounded in the greater use of the language that was wanted to learn during the teaching process of a second language. The Direct approach was invented as a contrast to the Grammar-Translation approach.

\section{Content and Language Integrated Approach (CLIL)}

The Integrated Content and Language Approach (CLIL) is a teaching and learning methodology in which the mother language and the second language stimulate the acquisition of content and language. This method attempts to manage the affective side of students by creating a safe learning environment where students help to establish rules in the class and are participants in their learning, intending to make the learning visible so that the students can experience and discuss the language as well as the focused learning contents in generating a great expectation in students and teachers.

The high level of engagement for all students and the independence of language and cognition may be visible with CLIL to create the academic language visible reflected on the learning, 
to promote critical thinking and also taking the time for making learning meaningful. This method uses language and content scaffolding that is reflected in teaching. This approach intends to promote the learner's autonomy giving them choices to make and negotiating decisions about the learning process with students. CLIL uses cooperative learning to promote positive independence for real life, interaction, and teamwork. CLIL method is always connecting language speaking with culture (Gordillo, 2018).

\section{Communicative Approach}

The above- explains method CLIL is regarded as part of the communicative branch because its main objective is for students to learn a second language to the point where they are able to use it in a natural way. The communicative method is based on their own experience to reach learning and that these experiences are important for their future lives.

\section{Total Physical Response Approach (TPR)}

This method was created by James Asher (1960) and which was based on the learning of a second language through the physical response of orders made by teachers to students repeatedly. With this method, the students will develop their listening skills much earlier than the communicative ones. Besides, there is no forced desalination in oral communication, but it takes a while to achieve the comfort of the student to start talking and communicating. Being able to achieve a successful teaching method is truly a challenge due to the different levels and rhythms of student learning and the way teachers teach in the classroom. Knowing the objectives of teaching and the teaching environment and to the students are fundamental elements for the utilization of any of the important methods previously exposed.

\section{Multiple Intelligences}

The model of multiple intelligences presented by Howard Gardner (1983), has transformed the mode how people comprehend all the intelligences in humans and experiments the clue of a sole IQ, where human beings have one dominant processer inside the brain where brainpower is deposited. Howard Gardner, firstly was the person who offered the model, saying that there are numerous categories of intelligence in people, each one demonstrating diverse conducts of treating information. The kinds of bits of intelligence proposed by Gardner are the following:

- Verbal-linguistic intelligence is the ability to scrutinize material and to produce work that encloses oral and written language, such as discourses, books, and emails.

- Logical-mathematical intelligence is the capacity to develop comparisons and proofs, make calculations, and solve abstract problems.

- Visual-spatial intelligence This intelligence permits people to understand maps and other types of graphical information. 
- Musical intelligence enables people to produce and make meaning of diverse kinds of sounds.

- Naturalistic intelligence is the ability to identify and distinguish between different kinds of plants, animals, and weather constructions located in the natural world.

- Bodily kinesthetic intelligence needs to use the body itself to produce products or solve problems.

- Interpersonal intelligence Skill to identify and understand other people's moods, personalities, wishes, motivations, and intentions.

- Intrapersonal intelligence is the skill that recognizes and assesses equal characteristics within themselves.

\section{The illustrated stories used in English language learning.}

According to Mourao (2009), there are many authors who support the use of stories since they are a source as a teaching method in learning the English language. Many linguistic, cognitive, socio affective and aesthetic aspects are linked to the use of stories in the teaching of English as a second language. Many authors include drawings in their storytelling, as this is an effective way to attract attention, especially from children. These stories develop creativity in all students to promote critical thinking in the acquisition process in a second language.

The human being is exposed to the narrative in different subjects since birth, and when children are able to read, these stories provide them with new vocabulary unconsciously. Thanks to the creativity, motivation and empathy generated by stories in children, their brains process information from a different perspective (Saxby, 2016).

\section{Intervention Proposal}

\section{Contextualization of illustrated tales}

The elaboration of these two tales for a CLIL class in a pedagogic had required a big effort and two tales were chosen from some traditional narrations from Ecuador. Figure 1 shows the first tale named as Jumandy the Amazonic Warrior comes from the Highlands, while Figure 2 the story between Juan and the Taita Chimborazo from the Amazon region. The element to create the tales were the methods to design them, the vocabulary according to the Primary educational level and also their possible positive and negative impacts that they will have in the Primary Education students.

Another important point taken to the design of these tales was to encapsulate the main students' likes and needs, the language, and the all the content and lastly, also the importance to shown traditional not well-known tales from Ecuador (Gordillo, 2018). 


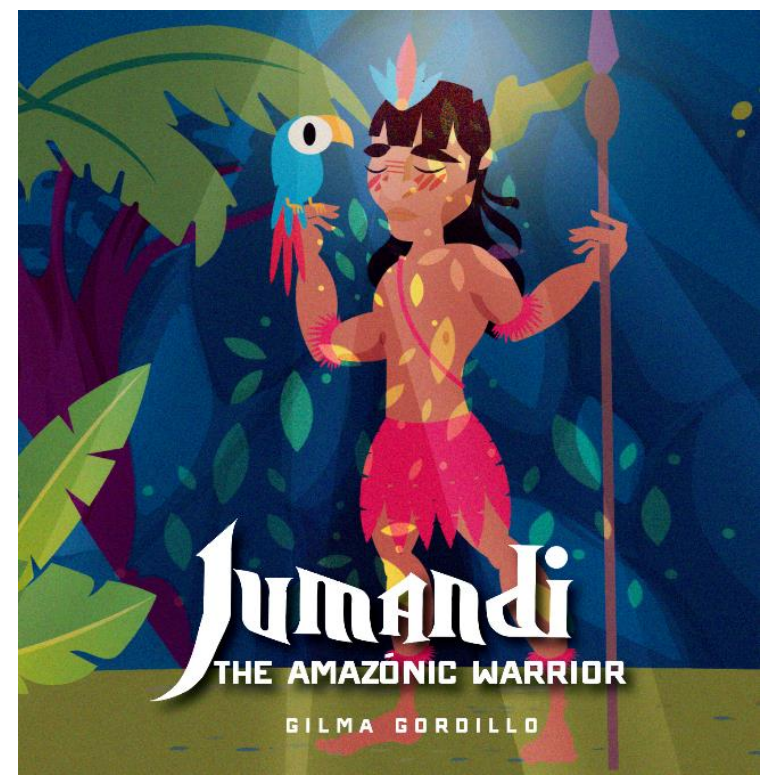

Figure 1. Jumandy The Amazonic Warrior

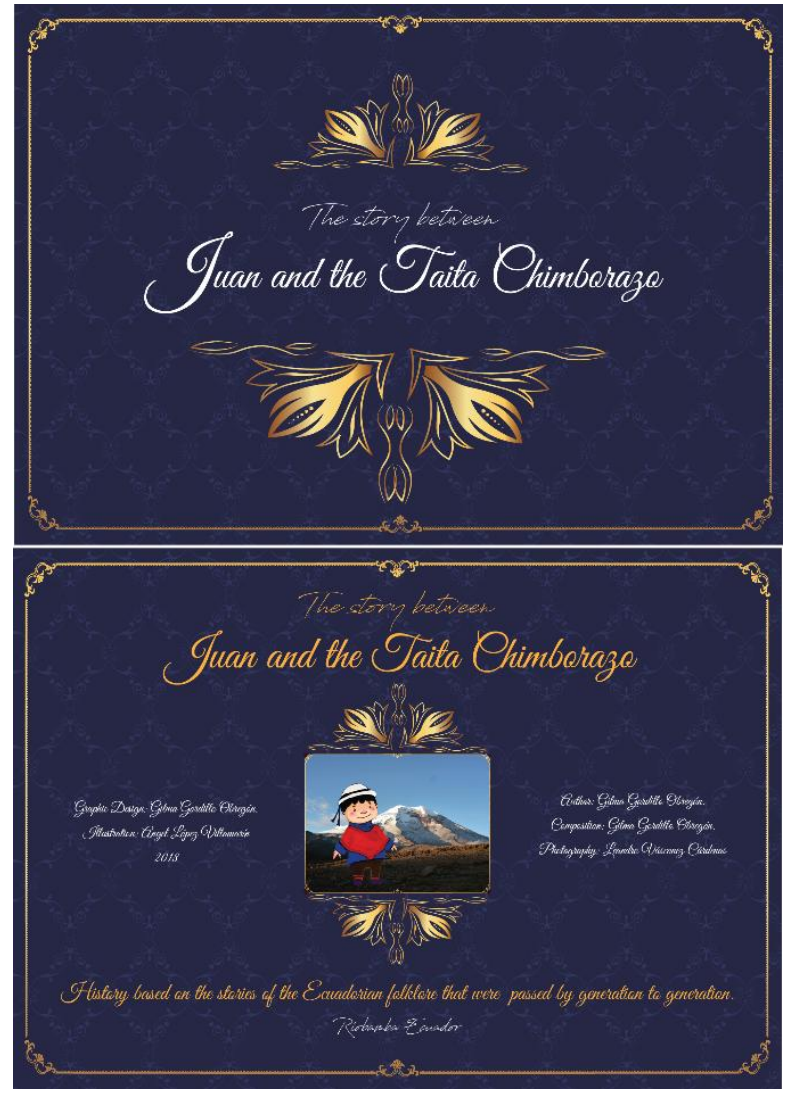

Figure 2. The Story between Juan and the Taita Chimborazo 


\section{Discussion}

The combination of the CLIL approach and the multiple intelligences in this intervention proposal using two tales to help to improve the learning process in students in the Primary School Education in Ecuador and in the bilingual programs using English as a second language.

The principal purpose of this project is to include the student's contribution in their learning process in a motivating way and also activating their knowledge with their conscience to learn through the activities and the unit. Thus, the proposal was grounded on a communicative methodology with two parts. The part number one with two illustrated tales which both were created to support the learning process based in the language and the content, where the main plan of them was to develop the student's skills.

Both tales were created with different activities to elevate the learning in students. In the second part, the planning of two activities that will support the proposal was designed to promote their skills and the learning of new knowledge, the $4 \mathrm{Cs}$, and the competences. The intentional section with an example activity in class was presented and may be helpful to students to understand that, everyone has the same opportunity to learn and we all are intelligent in a different way.

Concerning the elaboration of the tales was finished including CLIL approach, the 4Cs, and (MI) multi-intelligence ideas. As an outcome, the cognition of content communication and the culture was integrated as well as with the central context. Communication has played the most important role of all, seeing language through learning. Scaffolding as a teaching approach was considered as an active and unique learning process in the proposal. Within the activities, students are encouraged to work independently and also in a group to improve their higher order of thought and knowledge. construction.

This intervention proposal has been designed to be implemented in a Primary Bilingual School focusing on CLIL and the multiple intelligences to help the learning process rise in students. The activities and the content are specific, the methodology proposed could be adapted to many contexts also to secondary level, where students with a certain level of autonomy and skill gather much experience and more informational synthesis. The complete proposal was made to create consciousness of all the multiple intelligences to make the students know which learning strategy is more useful for them.

\section{Conclusions}

- It can be said that the objective of this study has been to reach the usefulness of the theory that speaks of MI to create and provide learning strategies such as the two illustrated stories for primary school students in Ecuador in a CLIL class from a theoretical perspective to raise their learning in the classroom. 
- All the strategies of teaching and learning are always an excellent and exceptional learning tool that provides great support to the significant learning to the student and to the development for the achievement of triumphs and educational results. Conversely, differences personalities and ways of learning from personal and between students make it truly impossible to use all teaching strategies for a particular type of activity as for other sensory channels. Consequently, it is settled that the learning strategies should be used according to the personal characteristics of the students and the class.

- I believe that the application of the two illustrated stories will affect positively in students and teachers that may have to adapt to a great change in the teaching and learning methodology. A big change of minds, in the way of providing information and contributions to students, how educational activities can be related to content and language, and how the student can be evaluated in different ways through the use of activities and resources for teaching and not only with memorized written and oral tests. The Multi Intelligence can be applied in many different ways, with the use of CLIL as a new educational method of teaching and learning in the classroom; knowing that IMs are not connected to CLIL, but that they always allow their implementation without much difficulty elevating the learning process in students.

- Important aspects that must have in mind when talking about CLIL are some to mention for example, the use of a visual communication support students, the use of learning based on creative thinking with the practical application of projects and tasks inside and outside the classroom, and the fact of promoting the creation and education of critical, proactive and independent students to include all the intelligences they may have in their teaching and learning plan. An example of these practical aspects implemented in this project there are the two illustrated stories presented and designed as an intervention proposal, which are focused on being an educational input support made by the teacher as a didactic resource to give an entry tool to the students, in which the content and the language could be taught in different ways with a creative and active activity, using different bits of intelligence to create a final product made by students as a final project after the intervention proposal as the proposed essay and the role play.

- In order to evaluate our proposal for intervention, questions will be asked before and after the proposal, as well as work evaluation within the class in an individual way and in teamwork. Finally, an individual evaluation is carried out with the realization of an essay based on the contents, the language and the proposal designed for teaching-learning.

- It can be concluded in this way that the proposal presented in this project will be a positive educational resource for bilingual education in Ecuador to improve multiple intelligences and students' learning approach based on CLIL 


\section{Bibliographic References}

Asher, J. (2006). What is TPR. tprworld, 10. Retrieved from http://www.tprworld.com/what.html

Ecuador, R. O. (2011). Retrieved from Ley Organica de Educacion Intercultural: https://www.wipo.int/edocs/lexdocs/laws/es/ec/ec023es.pdf

Gardner, H. (1983). Frames of Mind: The Theory in the following way. New York: Basic Books.

Gardner, H. (2006). Multiple Intelligences. New horizons. New York: Basic Books.

Gardner, R., \& McIntyre, P. (1993). A student's contributions to second-language learning. part.11. Affectivevariables. Leanguage Teaching. Ney York.

Gordillo, G. A. (2018, Septiembre). The use of illustrated tales: a proposal to improve Multiple intelligences and student's learning approach based on CLIL. Retrieved from Re-Unir Repositorio digital: https://reunir.unir.net/bitstream/handle/123456789/7650/GORDILLO\%20OBREGO N\%2c\%20GILMA.pdf?sequence=1\&isAllowed=y

Loannou, S., \& Pavlou, P. (2011). Implementation in Primary and Pre-primary Education. Cyprus: Education and Culture.

Marsh, D. (2002). Content and Language Integrated Learning: The European Dimension Actions, Trends and Foresight Potential. Jyväskylä: Unicom.

Marsh, D., Pavon, V., \& Frigols, M. (2013). The Higher Education Languages Landscape: Ensuring Quality in English language Degree Programmes. Valencia.

Mourao, S. (2009). Using Stories in the primary Classroom. Barcelona.

Muñoz, c. (2002). Aprender Idiomas. Barcelona: Paidos.

Richards, J., \& Rodgers, T. (2011). Aproches and Methods in Language Teaching. Cambridge: Cambridge University Press.

Saxby, K. (2016). Learning English through stories. Retrieved from Cambridge: http://www.cambridgeenglish.org

Thornbury, S. (2010). G is for Grammar Translation. Scottthornbury. Retrieved from https://scottthornbury.wordpress.com

Williams, M., \& Burden, R. (1998). Psychology for language teachers. approach of social constructivism. Madrid: Cambridge University Press. 


\section{PARA CITAR EL ARTÍCULO INDEXADO.}

Gordillo Obregon, G., Obregon Mayorga, A., \& Logroño Becerra, M. (2019). The use of illustrated stories as a proposal to improve multiple intelligences and students' learning approach based on CLIL. Ciencia Digital, 3(4.1), 98-112. https://doi.org/10.33262/cienciadigital.v3i4.1.985

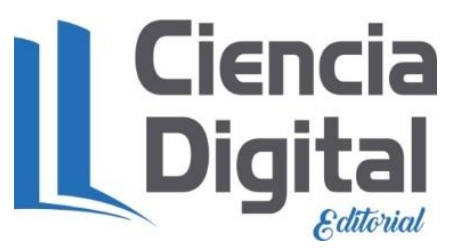

El artículo que se publica es de exclusiva responsabilidad de los autores y no necesariamente reflejan el pensamiento de la Revista Ciencia Digital.

El artículo queda en propiedad de la revista y, por tanto, su publicación parcial y/o total en otro medio tiene que ser autorizado por el director de la Revista Ciencia Digital.
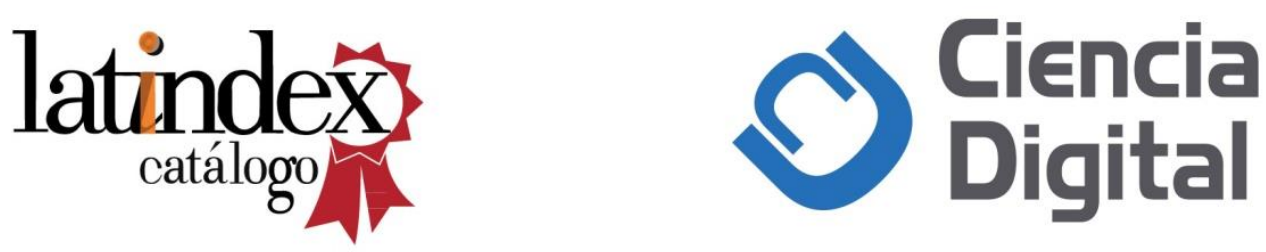